\title{
THE NUMBER OF MISSING PERMANENT MOLAR TEETH BASED ON CHARACTERISTICS OF RESPONDENT ON LUBUK BUAYA PUBLIC HEALTH CENTER
}

\author{
Murniwati $^{1 *}$, Susi ${ }^{1}$, Nila Kasuma ${ }^{1}$ and Nilma Rawinda ${ }^{1}$ \\ ${ }^{I}$ Faculty of Dentistry, Andalas University, Padang, Indonesia
}

\begin{abstract}
Permanent molar are the teeth that mostly missing. In Padang, the Caries Index is 2.78, Missing-Teeth Index is 2.29, Missing Teeth Index percentage is $82.4 \%$ with $9.2 \%$ of denture usage. Lubuk Buaya Public Health Center has the highest number of permanent tooth extraction in Padang. The purpose of this study is to look at the relationship of number of missing permanent molar teeth with the characteristics of respondent. The design of this study is using descriptive method. The number of samples are 97 respondents with age range between 25-44 years-old, who live in Lubuk Buaya Public Health Center working area that meet inclusion criteria. About 90,7\% of respondents lost 1-4 permanent molar while 9,3\% respondents lost 5-8 molar. Most of male (84.6\%) and female (97,8\%) lost 1-4 molar teeth. Almost all of age range lost 1-4 molar. All respondent with only elementary school level of education lost 5-8 molar teeth, while other level of education lost 1-4 molar. Gender, age and the level of education affect the number of missing permanent molar teeth on Lubuk Buaya Public Health Center working area. Lower education level lead to the higher number of missing permanent molar teeth.
\end{abstract}

Keywords: permanent molar teeth, characteristics of respondent

\section{Introduction}

Tooth loss increases with age as a cumulative impact of caries, periodontal disease, and treatment failure or trauma. Nicola et al., stated that permanent molars are the most missing teeth compared with premolars, canines and incisors (Damyanov, 2012).

The impact of losing one permanent molars if it not replaced with dentures are the pathological migration of the adjacent teeth and antagonists, periodontal trauma, interdental caries, loss of contact points due to migration, gingival recession, calculus, and premature occlusion. The mastication function will be disrupted if it loses some permanent molars. If 4 teeth are missing it will cause 8 teeth that are not working for mastication. If the total number of teeth is 32 then $25 \%$ of chewing efficiency decreases so that interrupt nutrient intake (Arifzan, 2010). Omar states that the loss of all or most of the molar teeth will have an occlusal impact, decreasing the vertical dimension of the face. If tooth has been loss for a long time period, it may cause interference with Temporomandibular Joint (Omar, 2001).

Basic Health Research (Riskesdas) stated that to achieve the target of health services in 2010, various programs such as promotive, preventive, protective, curative and rehabilitative have been conducted. World Health Organization set indicators, including 5 years old children $90 \%$ are caries free, 12 years old children has dental caries damage (DMF-T index) of one tooth, the dental-extraction-free of 18-year-old population (component $\mathrm{M}$ $=0$ ), the population aged 35-44 had at least 20 teeth by $90 \%$, the population aged 65 and older still had teeth works by $75 \%$, and people without teeth is $\leq 5 \%$.

The DMF-T index in Indonesia is 4.8 with the M-T (Missing Teeth) index of 3.9. This means that on average 5 tooth damage per person, an average of 4 teeth per person is extracted. The percentage of MTI (Missing Teeth 
Index) in Indonesia is $79.6 \%$, while the percentage of fixed and removable denture usage is only $4.5 \%$. In West Sumatra the DMF-T index is 5.3, M-T 4.3, MTI $81 \%$ and the percentage of denture usage is 5.8\%. In Padang City, DMF-T index was 2.78, M-T 2.29, MTI 82.4\% with percentage of denture

usage is 9.2\% (Riskesdas, 2007). The most permanent dental extraction from 20 Puskesmas in Padang City in 2011 is the Lubuk Buaya Health Center.

\section{Materials and method}

This study describes the number of missing permanent teeth based on the characteristics of respondents, such as gender, age, and education of respondents with descriptive research design. Sampling was done by purposive sampling method. Data were obtained from 97 respondents with age range 25-44 years. The data were collected through interview method by using questionnaire which consisting independent variable (characteristic) and dependent variable (number of permanent molar tooth loss) at Lubuk Buaya Public Health Center from Koto Tangah Sub-district office. To see the relationship of the two variables, Chi-square test was used with $p$ value 0.05 .

\section{Results}

The frequency distribution of respondents based on characteristic of gender is shown in Table 1.

Table 1 Frequency distribution of respondents based on characteristic of gender

\begin{tabular}{llll}
\hline No & Gender & F & $\%$ \\
\hline 1 & Male & 42 & 43,3 \\
\hline 2 & Female & 55 & 56,7 \\
\hline & Total & 97 & 100 \\
\hline
\end{tabular}

The number of female respondents were more than male respondents.

Distribution of respondent characteristics by age can be seen in Table 2 .

Table 2 Distribution of respondent characteristics by age

\begin{tabular}{llll}
\hline No & Age (y.o) & F & $\%$ \\
\hline 1 & $25-29$ & 40 & 41,2 \\
\hline 2 & $30-34$ & 18 & 18,6 \\
\hline 3 & $35-39$ & 12 & 12,4 \\
\hline 4 & $40-44$ & 27 & 27,8 \\
\hline & Total & 97 & 100 \\
\hline
\end{tabular}

Most of respodents are coming from 25-29 years age group as shown in Table 2.

The frequency distribution of respondents based on education level characteristics can be seen in Table 3 . 
Table 3 The frequency distribution of respondents based on education level characteristics

\begin{tabular}{llll}
\hline No & Education Level & F & $\%$ \\
\hline 1 & SD & 6 & 6,2 \\
\hline 2 & SMP & 10 & 10,3 \\
\hline 3 & SMA & 46 & 47,4 \\
\hline 4 & DI & 1 & 1,0 \\
\hline 5 & DII & 1 & 1,0 \\
\hline 5 & D III & 3 & 3,1 \\
\hline 6 & S 1 & 29 & 29,9 \\
\hline 7 & S 2 & 1 & 1,0 \\
\hline Total & & 97 & 100 \\
\hline
\end{tabular}

The highest education level of most respondents is high school level.

The frequency distribution of the number of permanent tooth loss respondents can be seen in Table 4 .

Table 4 Number of Permanent Molar Dental Losses in Community Aged 25-44 y.o. in Lubuk Buaya Public Health Center

\begin{tabular}{lll}
\hline $\begin{array}{l}\text { Number of } \\
\text { Permanent Molar } \\
\text { Losses }\end{array}$ & $\mathrm{F}$ & $\%$ \\
\hline $\begin{array}{l}\text { 1-4 permanent } \\
\text { molars }\end{array}$ & 88 & 90,7 \\
\hline $\begin{array}{l}\text { 5-8 permanent } \\
\text { molars }\end{array}$ & 9 & 9,3 \\
\hline Total & 97 & 100 \\
\hline
\end{tabular}

Most of respondents lost 1-4 permanent molars

Table 5 Relation of Gender of Respondent to Number of Molar Teeth Loss

\begin{tabular}{lllll}
\hline \multirow{2}{*}{ Gender } & \multicolumn{2}{c}{ Number of Molar Loss } & \\
\cline { 2 - 3 } & $1-4$ teeth & $5-8$ teeth & & \\
\hline Female & $84,6 \%$ & $15,4 \%$ & $100 \%$ & \\
\hline Male & $97,8 \%$ & $2,2 \%$ & $100 \%$ & 0,035 \\
\hline
\end{tabular}

Table 5 shows the results of the analysis of the relationship between the gender with the number of permanent molar tooth loss, as many as $44(84.6 \%)$ female respondents and $44(97.8 \%)$ of male respondents lost 1 to 4 permanent molars. From the result of chi square statistic test, obtained the $p$ value $=0.035$ with $p<0,05$, hence there is significant relation between gender with amount of permanent molar tooth loss. 
Table 6 Relation of Age of Respondents with Number of Molar Teeth Loss

\begin{tabular}{|c|c|c|c|c|}
\hline \multirow{2}{*}{ Age (y.o) } & \multicolumn{2}{|c|}{ Number of Molar Loss } & \multirow[t]{2}{*}{ Total } & \multirow[t]{2}{*}{$P$} \\
\hline & 1-4 teeth & $5-8$ teeth & & \\
\hline $25-29$ & $97,5 \%$ & $2,5 \%$ & $100 \%$ & \multirow{4}{*}{0,005} \\
\hline $30-34$ & $100 \%$ & 0 & $100 \%$ & \\
\hline $35-39$ & $91,7 \%$ & $8,3 \%$ & $100 \%$ & \\
\hline $40-44$ & $74,1 \%$ & $25,9 \%$ & $100 \%$ & \\
\hline
\end{tabular}

Based on table 6 , it can be seen the results of the relationship analysis between age with the number of permanent molar tooth loss. The data show that 18 (100\%) of respondents with age range 30-34 years lost 1-4 permanent molars. Then $7(25.9 \%)$ of respondents with age range 40-44 years lost 5-8 permanent molars. From the results of chi square statistical tests, obtained $p$ value $=0.005$, then there is a significant relationship between age with the number of permanent molar tooth loss.

Table 7 Relation of Education Level of Respondent with Number of Molar Teeth Loss

\begin{tabular}{|c|c|c|c|c|}
\hline \multirow{2}{*}{ Education Level } & \multicolumn{2}{|c|}{ Number of Molar Loss } & \multirow{2}{*}{ Total } & \multirow{2}{*}{$P$} \\
\hline & $1-4$ teeth & $5-8$ teeth & & \\
\hline $\begin{array}{l}\text { Elementary Shool } \\
\text { (SD) }\end{array}$ & $0 \%$ & $100 \%$ & $100 \%$ & \multirow{4}{*}{0,000} \\
\hline $\begin{array}{l}\text { Junior High School } \\
\text { (SMP) }\end{array}$ & $100 \%$ & $0 \%$ & $100 \%$ & \\
\hline $\begin{array}{l}\text { Senior High School } \\
\text { (SMA) }\end{array}$ & $93,6 \%$ & $6,4 \%$ & $100 \%$ & \\
\hline $\begin{array}{l}\text { College / University } \\
\text { (PT) }\end{array}$ & $100 \%$ & $0 \%$ & $100 \%$ & \\
\hline
\end{tabular}

Based on table 7, it can be seen the result of the relationship analysis between the level of education with the number of permanent molar tooth loss. The data show that 6 people (100\%) of respondents with Elementary School Education level (SD) lost 5-8 permanent molars. While 100\% of respondents the level of Junior High School Education level and College level lost 1-4 permanent molars. In the high school education group there were 44 people $(93.6 \%)$ losing 1-4 permanent molars. From the results of chi square statistical test, it obtained $p$ value $=0.000, \mathrm{p}<0.05$, then there is a significant relationship between education level with the number of permanent molar tooth loss.

\section{Discussion}

Based on the number of tooth loss, 9 respondents $(9.3 \%)$ lost 5 to 8 permanent molars and 88 respondents $(90.7 \%)$ lost 1 to 4 permanent molars. The first permanent lower left molars are the most commonly extracted teeth, with as many as $87(20 \%)$. This is because permanent molar are the first teeth to erupt also are the longestused teeth, so they are often destroyed/decayed and then extracted. In addition, there are still many people who think if the first permanent molars are extracted then there will be a replacement due to eruption in the period of mixed teeth (Hedge, 2011).

Based on the annual report of Padang City Health Office 2014, dental disease is one of 10 most common diseases in the Public Health Centers. People usually comes after the tooth has pulp disorder. This led the ratio of fill and extraction in the city of Padang to 0:28 while the target is 1:1.7 
The cause of permanent tooth loss according to research conducted by Montandon (2012) is caries. The molar teeth are the largest and have pits and fissures. This surface is the most sensitive part to caries. The sensitivity of the occlusal surface to caries is due to the morphology of the pits and fissures. Food debris and bacteria will be trapped in a narrow and deep pit and fissure, not allowing toothbrush fibers to be able to clean it so caries will occur in that area.

Based on the result of chi square statistic test, it is obtained that the $p$ value $<0,05$, this means there is a significant relation between characteristic of respondent with amount of permanent molar tooth loss in Work Area of Lubuk Buaya Health Center.

Respondents of male and female gender have the same pattern which mostly have lost 1-4 permanent molars, as reflected in 44 female respondents $(84.6 \%)$ and 44 male respondents $(97.8 \%)$.

Respondents aged 35-44 years who lost 5-8 permanent molars were 8 respondents (88.9\%). Respondents aged 30-34 years who lost 1-4 permanent molars were 18 respondents (100\%). Respondents aged 25-29 years lost 1-4 permanent molars were 39 respondents (97.5\%). This is in line with Agtini research (2010) which states that tooth loss increases in the age group of 35-44 years. ${ }^{9}$ Permanent molar loss increases with age because permanent molar are the first teeth to erupt so they are often destroyed/decayed and then extracted.

Based on education level, most of the respondents came from high school education level, which is 46 respondents $(47,4 \%)$. All respondents with elementary school education lost 5-8 tooth. While all respondents with the final education is junior high level and college level, lost 1-4 teeth. This indicate that number of tooth loss is increasing if the final level of education is lower.

Higher level of education will lead to higher level of people knowledge about the impact of permanent molar loss. This is because the role of education is to increase knowledge, generate positive traits, and community capacity (Notoadmodjo, 2003). Higher level of education will lead to higher level of people awareness to maintain oral health. If a person maintains good oral hygiene then the amount of tooth loss can be minimized, because the teeth with extraction indication will also be minimized.

Knowledge is essential to the formation of person's actions, knowledge will affect a person in adopting behavior (Notoatmodjo, 2003). In addition, according to Zaini et al (2002) knowledge is the memory of the material studied, which includes the memory of the material of the facts and complete theories, will be reflected from someone's actions.

Based on the results of this study, it is found that there is a significant relationship between gender, age and education level of society with the number of permanent molar tooth loss in the Work Area of Publick Health Center Lubuk Buaya.

\section{Conclusion}

The number of permanent molar tooth loss is affected by gender, age, and final education level. Loss of 5-8 permanent molars was experienced by most of the respondents with elementary school education level.

\section{Acknowledgements}

The authors would like to thanks to Andalas University and the Ministry of Research, Technology and Higher Education of Indonesia for all support given to this research. 


\section{Reference}

Agtini, Magdarina Destri (2010). Percentage of Use of Protesa in Indonesia. Padang. Media Litbang Kesehatan 20 (2), 50

Arifzan, Ratna Hartati (2002). The Role of Permanent First Molar in Orthodontic Treatment. Journal PDGI.

Damyanov, Nicola D, Dick J. Witter, Ewald M. Bronkhorst, Nico H. J Creugers (2012). Dental Status and Assosiated Factors in a Dentate Adult Population in Bulgaria: a Cross Sectional Survei. Hindiawi Publishing Corporation.

Hedge, N, Mitra, AS Shija (2011). Carious First Molar in South Canara Population - An Epidemiological Study. Jida, vol 5, no 11.

Montandon, Andreia ( 2012 ). Prevalence and Reasons for Tooth Loss in a Sample from a Dental Clinic in Brazil.International Journal of Dentistry

Montandon, Andreia ( 2012 ). Prevalence and Reasons for Tooth Loss in a Sample from a Dental Clinic in Brazil.International Journal of Dentistry

Ministry of Health of Indonesia (2008). Basic Health Riset. 2007.

Notoatmodjo, Soekidjo (2003). Health Education. PT Rineka Cipta. Jakarta.

Notoatmodjo, Soekidjo (2010). Health Research Methodology. PT Rineka Cipta, Jakarta.

Omar, Ridwaan (2001). The Evidence for Prosthodontic Treatment Planning for Older, Partially Dentate Patients. Med princ pract 2003; (suppl 1): 33-42

Padang City Health Office (2014). Ministry of Health of Indonesia

WHO, Oral Health. Fact Sheet. Available in http://www.who.int/mediacentre/factsheets/fs318/en

Zaini, Hisyam ( 2002 ). Aktive Learning Education in PT Yogyakarta.CTDS 